IMPACT OF PARENTAL ANTIBIOTICS (AB) IN THE FECAL FLORA OF NEWBORN AND INFANTS.

Y. AUJARD, N. LAUDIGNON, E. JACQZ, M. COACHE, E. BINGEN, N. LAMBERT-ZECHOUSKI, H. MATHIEU.

Digestive tract troubles and selection of resistant are the known effects of $(A B)$. We demonstrated that they can also give a disturbance of the intestinal microbial ecosystem (IME), causing overgrowth and/or decrease or disappearance of certain bacterial species. The bacterial overgrowth in (IME) can be the starting point of secondary systemic infections in newborn.

MATERIAL AND METHODS: The effects of 10 (AB) were analyzed using the differential qualitative and quantitative technic which numerates all the bacteria present in the fecal flora. In 20 neonates having a secon dary systemic infection, we studied the modifications of the (IME) sequentially, before, during and after $A B$.

RESULTS : I - (AB) given by parenteral route, if they are secreted in the intestinal tract, can cause a microbial overgrouth depending of the $(A B)$ administered : Penicillin $G(6): E$. coli + Klebsiella ; Ampicillin (11) : Klebsiella + Enterobacter ; Cefotaxime (25) : Pseudomonas aeruginosa ; Cefoperazone (9) : yeasts ; Cefotiam (10) : Enterobacter ; Fasfomycin (7) : Enterobacteriacae ; Mezlocillin (9), Colistin (11), Aminoglycosides (25) : no overgrouth.

2 - In 20 neonates with a septicemia accuring during ( $A B$ ), we demonstrated the sequence : normal (IME) before (AB); overgrouth of a bacterial species during $A B$ and septicemia due to the same bacterial spe $J$ cies, in a variable delay. (AB) in cause were Ampicillin (10), Penicillin $G(6)$ and Cefotaxim (4).

CONCLUSIONS : The (AB) effects in the equilibrium of the (IME) must ba kept in mind to explain most of the acquired infection in newborn.

\section{THE FUNCTION OF PHAGOCYTES IN THE NEWBORN}

$L$ Benlíl, S Rabat lć $c^{3}$, A Sabloncel lo $0^{3}$ M Kasum ${ }^{2}$ B Stampar-Plasaj ${ }^{1}$. Depts. Pediatrics 1 , Obstetrics ${ }^{2}$, Inst. Immunology3 UnIversity of Zagreb, Yugoslavla

Leucocyte-medlated phagocytosis, ant ibody-dependent cellular cytotoxi. Ity (ADCC) and digestion of opsonlzed sheep erythrocytes were tested in 70 healthy newborns, 12 newborns with perinatal infect ion and 137 healthy adult controls.

$A D C C$ for opsonized $51 \mathrm{Cr}$-erythrocytes significantly decrease in the heal thy newborns, while newborns with perinatal infect lon increase thls activity as a defence function.

Phagocytosis of leucocytes confl rm the results of normal values in normal circumstances, whl le in the case of perinatal infection a weaker activity can appear, especlally in the male sex.

The dlgestion of the opsonlzed sheep erythrocytes Indlcates that the metabolic activity of leucocytes is well developed in the newtorn.
IPHAGOCYTIC FUNCTIONS OF HUMAN MILK MACROPHAGES.

Ch.P. Speer, M. Gahr, Department of Pediatrics, University of Göttingen, F.R.G.

Human milk is a suspension of viable cells; macrophages ( $M \phi)$ are the most abundant cells, comprising 40-80\% of the total cell count. The present study was initiated to examine the principal cell functions of phagocytic milk $M_{\phi}$ : adherence, chemotaxis, killing and phagocytosis-associated oxidative metabolism. Adherence of milk $\mathrm{M \phi}$ to nylon wool was significantly decreased when compared with blood monocytes, chemotaxis of $M \phi$ in response to $\mathrm{C} 5 \mathrm{a}$ or a synthetic chemotactic peptide was also decreased. However, $M \phi$ generated luminol-dependent luminescence, superoxide anion $\left(\mathrm{O}_{2}\right)$ and hydrogen peroxide $\left(\mathrm{H}_{2} \mathrm{O}_{2}\right)$ to a similar extend as blood monocytes after stimulation with opsonized zymosan or phorbol myristate acetate (PMA). In addition, M\$ killed Escherichia coli and Staphylococcus aureus as effectively as did blood monocytes coli and Staphylococcus aureus as effectively as did blood monocytes
$(275 \%, 120 \mathrm{~min})$. Acidification of milk (pH $1,30 \mathrm{~min})$ only slightiy reduced PMA-stimulated production of oxygen radicals by $M \phi$. Bacterial killing by $M \phi$ preincubated at $\mathrm{pH} 1$ was about $70 \%$ that from controls maintained at $\mathrm{pH} 7$. When $M \phi$ were cultured for several days in endotoxin-free medium, their ability to produce oxygen metabolites declined. By continuous treatment with bacterial lipopolysaccharide (LPS, $10 \mathrm{ng} / \mathrm{ml}$ ), milk $M \phi$ could be "primed" to release large amounts of oxygen intermediates. The $0 \overline{2}$ response of $M \phi$ cultured without bacterial products could be partially restored by the addition of LPS to the culture. We conclude that milk M\$ are capable of releasing large amounts of oxygen metabolites, and could contribute to the protection of neonates against bacterial and fungal infections.

Supported by a grant from Deutsche Forschungsgeme inschaft

\section{CHRONIC GRANULOMATOUS DISEASE: A HETEROGENEOUS METABOLIC} R. Seger, M. Bohler, W.H. Hitzig, A. Fischer, E. Villmer, C. Griscelli Dept. Pediatrics, Univ. Zürich and Hopital Necker, Paris

25 patients with chronic granulomatous disease (COD) and members of their families were investigated to evaluate the biochemical heteropeneity of this syndrome. Defects in granulocyte $02^{-}$generation were enalysed by spectroscopy of the heme-containing cytochrome b. Four patterns were observed: 1) 17 of 21 typical (severely affected) CGD patients shoved complete absence of cytochrome $b$, the defect being linherited in an X-linked pattern. 2) In contrast, 4 of 21 typical patients had normal amounts of cytochrome $b$ and autosomal-recessive transmission of their disease. 3) In 3 patients with atypical (mild) CCD, residual $02^{-}$generation and low amounts of cytochrome $b$ were detected. This partial cytochrome $b$ deficiency is $X$-linked and may be pverlooked by conventional tests. 4) In one patient cytochrome b deficiency was associated with the McLeod syndrome (Kx-deficiency), a combination enabling the localisation of the cytochrome $b$ gene to the short arm of the X-chromosome near the Xk locus, identified as Xp2lxpter.

We conclude that cytochrome b deficiency is the most frequent but not the only defect underlying CGD and that it occurs in at least thre variants.

\section{SUPEROXTDE PRODUCTYON BY NEUTROPHILS OI} Doris Sobmidt, H. Köditz and J. Morenz (introduced by W. Marget, Müchen), Institut für Medizinisobe Mikrobiologie und Klinik für Kinderheilkunde der Medizinischen Akademie MagdeburB, GDR

To further elucidate the dependence of innate defense mechanisms against microorganisms on age, the superoride anion production (ferricytocbrome c reduction) of resting and stimulated (zymosan treated serum) neutrophils obtained from newborns (cord blood) and adults (venous blood) was investigated. Resting newborn neutrophils produced significantiy more superoxide than adult neutrophils significantly more superoxide than adult neutrophils
(p<0 05, t-test) with $8.93+4.01$ and $5.82 \pm 4.34$ nmole $/ 5$ $x 10^{6}$ oells/30 min, respeotively. There was no difference between stimulated noutrophils from newborns and adults and betweon resting and stimulated neutrophils from the mothers and otber adults. The quotient "stimulated/ resting" neutrophils was 3.7 in newborns and 6.0 in adults. The meaning of the difforent quotients with respect to the microbicidal capacity of newborn neutrophils remains to be eluoldated in futuro.

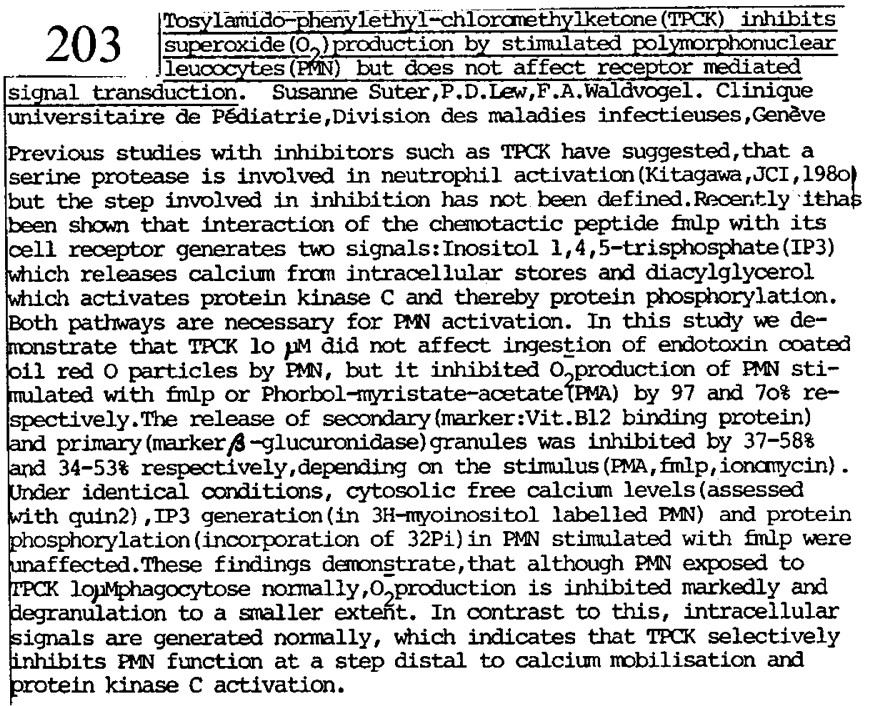

